\title{
Third Party Regulatory Information Submitter
}

National Cancer Institute

\section{Source}

National Cancer Institute. Third Party Regulatory Information Submitter. NCI Thesaurus.

Code C101710.

An outside party deleg ated to submit regulatory information. 